\title{
Ethnic conflicts and transition experiences in south-east Europe ${ }^{1}$
}

More than one decade has passed since the worst of the Third Balkan Wars (1991-5) in Croatia and Bosnia, since the war between Moldova and breakaway Transnistria (1992) and since the mass riots in Albania (1997). Equally, the Kosovo war (1998-9), and the unrest in Presovo (2000) and Macedonia (2001) have faded with, luckily, no renewed military violence in the region which, with 200000 killed -8000 of them the men and boys of Srebrenica alone - saw the worst mass violence in post-war Europe, rivalled in horror only by the wars in Chechnya and Stalin's death camps. It is obvious that the transformation prospects of the countries victimised by this ethnically-motivated violence have been seriously negatively affected but, in the light of the subsequent substantial period of ceasefire and peace, we can now judge better their aggregate extent, the effects of other economic and political variables, and the ways and means of redress: notably so, since almost the entire region, for about the last five years, has enjoyed a fairly good macroeconomic environment with growth rates around 5\%, low inflation and relatively little public and external indebtedness.

For comparative purposes, the diagram overleaf places the eleven countries of south-east Europe horizontally along an axis estimating the destructiveness of the ethnically-motivated conflicts in their own country, and indicates vertically the degree of success of their transition experience (measured as a multiple of their per capita income and the Bertelsmann transformation index - the combination of an objective and a subjective expert indicator). Ideally, if past violence and destruction were the main factor affecting transformation, then we should expect countries to be lined along the diagonal between Slovenia (experiencing relatively little violence back in 1991 and a high transformation success since then) on the top left and Kosovo (suffering severe violence and disruption during 1998/9 and little transformation success subsequently) on the bottom right. The diagram, however, represents a strikingly different picture.

Apart from Croatia (strongly affected by a destructive war and with an increasingly successful transformation since 1999), there are four clusters of countries which point to a dominance of other factors:

1. an EU cluster of no violence, including Slovenia, Romania and Bulgaria (covering $53 \%$ of the population of south-east Europe), with the latter two, however, underperforming in terms of transformation success

2. a low-performing mass unemployment cluster of Montenegro, Serbia and Macedonia (17\% of the population of south-east Europe), where one-quarter to onethird of the population are out of work

3. an emigration cluster of lesser-performing Albania and Moldova (13\% of the population of south-east Europe), living off remittances as one-third of the population has left

1 This article reflects the personal views of the author, not those of his employer. 
4. a protectorate cluster of Bosnia-Herzegovina and Kosovo (10\% of the population of south-east Europe), with half the population out of work, living on foreign aid ( $€ 5$ bn for $\mathrm{BiH}$ and $€ 2$ bn for Kosovo) and predictably little transformation.

Figure 1 - Ethnic wars and transition experience

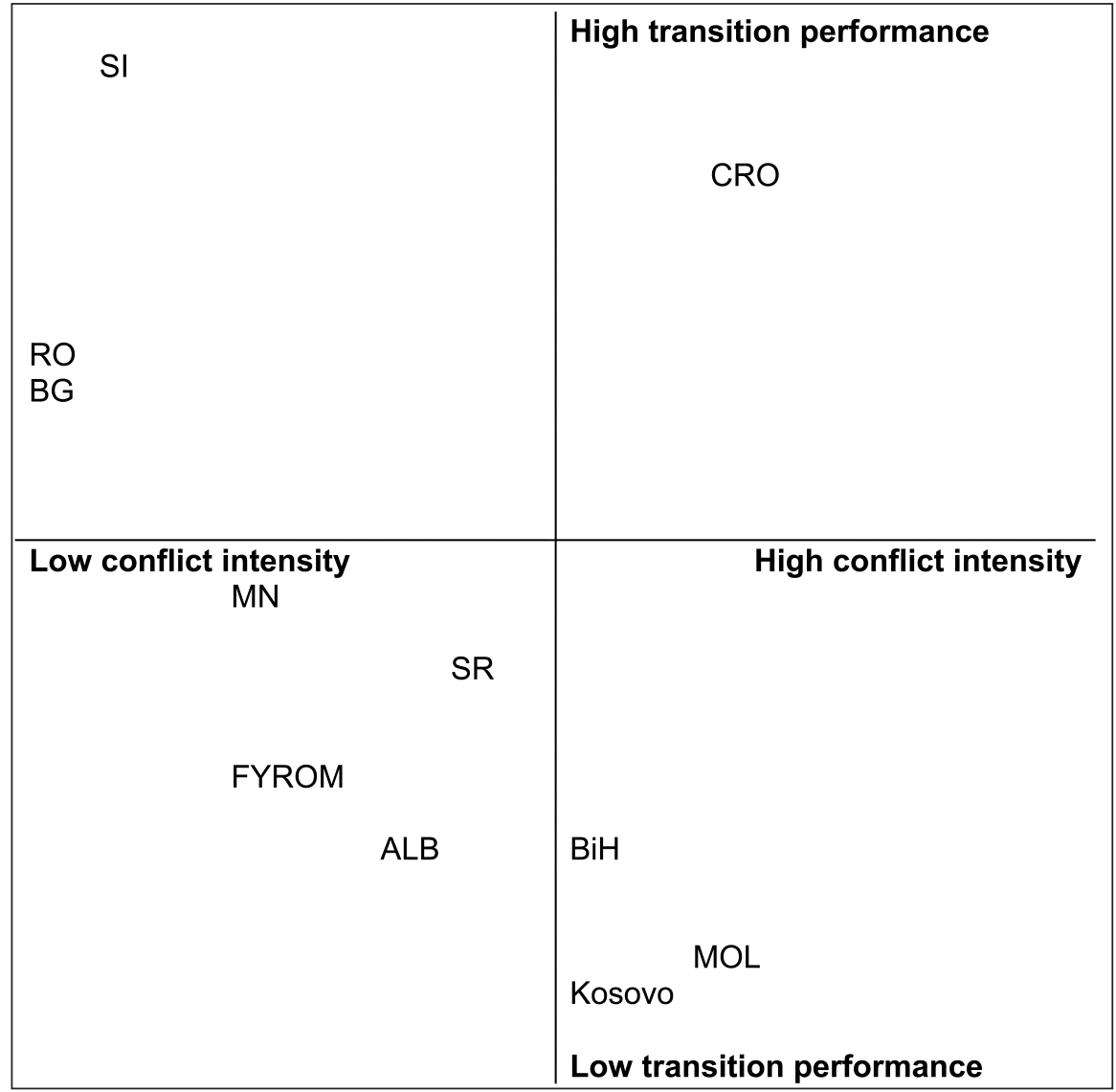

The more decisive variable explaining Slovenia's and Croatia's relative success and the degrees of under-performance of the others would, then, seem to be related to factors like work ethics, industrial tradition and the educational levels of the workforce as well as to the quality of governance (rule of law, protection of life and property, predictable and fair administrative procedures and an absence of corruption). Political risks, which still loom large in politically-divided countries like Albania, Moldova and Macedonia, as well as in the foreign-directed protectorates of Kosovo and $\mathrm{BiH}$, where a de-responsibilised political class is allowed to sponge on foreign aid and, like most leaders of aid-dependent countries, is disinterested in economic devel- 
opment, would also seem to be important. All previous approaches to $\mathrm{BiH}$, with its 150 ministers, have failed - those of aloof authoritarianism on the part of EU representatives Paddy Ashdown and Wolfgang Petritsch, and the one of gentle empowerment of Christian Schwarz-Schilling ${ }^{2}$ - as would any other method short of self-determined and self-reliant self-government.

A key effect of good governance is its attraction to FDI which (in deference to foreign aid, however well intended) alone supplies dearly-needed productive capital, access to new technologies and managerial and marketing know-how. Croatia leads the field on a per capita basis as does Romania, given its market size and assets, in absolute terms.

EU membership has long been seen as a panacea for all the region's problems, including its ethnic conflicts, and there have been bitter complaints as to why south-east Europe - as patently unprepared as most of its countries are - is so privileged in its promise of membership compared to other interested European countries (Ukraine, Georgia and Armenia, in particular). This promise is well and good, but needs to be hedged. The glory of Slovenia joining the Euro zone has, and will be in the months to come, sung loudly. The export and manufacturing window of Yugoslavia, Slovenia entered transformation in the relatively best position of all the former Communist countries. Believing that it could afford to do so, the political class of both camps has remained slow in privatisation and averse to large-scale reforms and most FDI. ${ }^{3}$ Rather than basking in the (self-)congratulation as the best-performing among the central and east accession countries, and certainly so in south-east Europe, a more productive and unpleasant question may be why Slovenia (having bypassed technology-averse Portugal) is still the second worst-performing economy in west Europe where it culturally now feels its place.

The experience of Romania and Bulgaria as EU members since January 2007 is certainly more dramatic. After Günter Verheugen, then Commissioner in charge of enlargement, ended negotiations with both in clearly unprepared sectors in return for solemn promises of future reforms, ${ }^{4}$ and the rest of the Commission, the European Council and majorities in the European Parliament and member states' parliaments concurred, promising membership by January 2007 (or 2008 at the very latest), both political classes decided to stop effective reform work and to refocus instead on their favourite past-times: political intrigue; power struggles; mutual blockages; and selfenrichment. ${ }^{5}$

In the meantime, it has dawned on many EU politicians in their public pronouncements that this last enlargement round was premature. ${ }^{6}$ Yet, this recognition has come

2 Michael Martens 'Bosnischer Blockade-Tango' Frankfurter Allgemeine 30 June 2007; Renate Flottau and Marion Kraske 'Am Rande des Abgrunds' Der Spiegel 7 November 2005 .

3 Albrecht Rothacher (2002) Im wilden Osten. Hinter den Kulissen des Umbruchs in Osteuropa Hamburg: Krämer Verlag, pp. 353.

4 Tom Gallagher 'Europe opens the door to an unreformed Romania' Financial Times 2 October 2006.

5 Michael Stabenow 'EU Beitritt mit Schönheitsfehlern' Frankfurter Allgemeine 14 September 2006; 'Verschämte Erweiterung durch die Hintertür. Bulgarien und Rumänien als Schmuddelkinder der EU?’ Neue Zürcher Zeitung 4 January 2007. 
too late. Hence, the European Commission, in various progress and monitoring reports, has been able only to take note of a range of continued shortcomings in both countries: large balance of payments deficits; problems in public infrastructure; problems in food hygiene; concerns over veterinary controls; financial administration and public procurement worries; issues in border protection; and the need to combat corruption, product piracy and money laundering; and, for Bulgaria in addition, air safety and organised crime - given the frightful frequency of unresolved contract murders, of which there have been some 150 since 2000 including three successive presidents of Locomotive Plovdiv alone.

The Romanian government reacted to the admonitions by firing Monica Macovei, the celebrated anti-corruption heroine, as Minister of Justice. Legal and procedural reforms enacted by her were quickly watered down. Romania has been promised $€ 30 \mathrm{bn}$ in agricultural and structural fund support during 2007-13, and Bulgaria $€$ $15 \mathrm{bn}$, but there is no assurance that these funds will per se aid their sustained development and urgently-needed catching up. If there are lessons to be learned, then those of Spain and Ireland, who put these funds to good use on improved infrastructure, education and for attracting FDI, clearly apply. If there are deterrent lessons, then there are those of Greece under the decades of PASOK rule (1981-2004), when annual EU transfers amounting to $6 \%$ of GDP were spent on a bloated public sector without leaving a trace in economic performance or productivity gains. The chances are that the EU's newest member states will follow the Andreas Papandreou school of rewarding friends with foreign money. True enough, EU membership this time has come with the threat of sanctions - the options are: a freezing of support funds; exclusion from EU legal policy decisions; non-recognition of corrupt court decisions; or a ban on livestock exports to the member states of the Union. After the first non-consequential Commission monitoring reports were out this spring, both governments seem to have concluded that these sanctions appeared pretty toothless. After paying due lip service to betterment, it was soon business as usual again. ${ }^{7}$

The antics of the two new member states (and those of some of the no longer such new ones) has surely achieved a serious aggravation of the public, and finally also of the official, enlargement fatigue, putting future EU memberships at serious risk. This would be a pity since one country - seriously damaged by war and reconstructed almost unassisted - has put its house in order, modernised its infrastructure, enacted minority protection, welcomed FDI and succeeded against all odds since 1999. But Croatia is not alone on a positive road: by most accounts, Montenegro and Serbia are well-placed and well-advised to follow its example, whatever the odds and time horizons of eventual EU membership.

6 Herbert Bösch 'Die Festlegung auf ein Datum war ein Fehler' Die Presse 26 September 2006.

7 George Parker, Kerin Hope and Christopher Con 'Europe's errant entrants. Brussels struggles to confront corruption within the new two' Financial Times 13 June 2007. 


\section{References}

Benderley, Jill and Kraft, Evan (eds.) (1997) Independent Slovenia Houndmills: St. Martin's Press.

Brunner, Georg (1996) Nationalitätenprobleme und Minderheitenkonflikte in Osteuropa Gütersloh: Bertelsmann Stiftung.

Calic, Marie-Janine (1996) Krieg und Frieden in Bosnien Hercegovina Frankfurt/M: Suhrkamp.

Federal Ministry of Foreign Affairs (1999) NATO Crimes in Yugoslavia Documentary Evidence Belgrade.

Gallagher, Tom (2002) Theft of a Nation: Romania since Communism London: Hurst and Co.

Glenny, Misha (1996) The Fall of Yugoslavia. The Third Balkan War London: Penguin.

Glenny, Misha (1999) The Balkans 1804-1999. Nationalism, War and the Great Powers London: Granta Books.

Lieven, Anatol and Trenin, Dimitri (eds.) (2003) Ambivalent Neighbors Washington: Carnegie Endowment.

Mommsen, Margaretha (ed) (1992) Nationalismus in Osteuropa München: Beck.

OECD (1998) Economic Study Romania Paris.

Rothacher, Albrecht (2002) Im wilden Osten. Hinter den Kulissen des Umbruchs in Osteuropa Hamburg: Krämer Verlag.

Rothacher, Albrecht (2005) 'Moldawien - Auswanderung statt Demokratie' KASAuslandsinformationen 5/2005: 32-43.

Schmid, Thomas (ed.) (1999) Krieg im Kosovo Reinbek: Rowohlt.

Simms, Brendan (2002) Unfinest Hour. Britain and the Destruction of Bosnia London: Penguin.

Tanner, Marcus (1997) Croatia. A Nation Forged in War New Haven: Yale University Press.

Weidenfeld, Werner (ed.) (1995) Demokratie und Marktwirtschaft in Osteuropa Gütersloh: Bertelsmann Stiftung.

Weidenfeld, Werner (ed.) (1996) Central and Eastern Europe on their Way into the EU Gütersloh: Bertelsmann Foundation.

Weithmann, Michael (ed.) (1994) Der ruhelose Balkan München: DTV. 